\title{
CSNK2B wt Allele
}

National Cancer Institute

\section{Source}

National Cancer Institute. CSNK2B wt Allele. NCI Thesaurus. Code C107445.

Human CSNK2B wild-type allele is located in the vicinity of $6 \mathrm{p} 21.33$ and is approximately 5 $\mathrm{kb}$ in length. This allele, which encodes casein kinase II subunit beta protein, is involved in the regulation of casein kinase II. 